\title{
Supramolecular Chemistry and Technology*
}

\author{
HENRIQUE E. TOMA** \\ Instituto de Química, Universidade de São Paulo, \\ Cx. Postal 26.077 - 05513-970 - São Paulo, SP, Brazil
}

Manuscript received on September 8, 1999; accepted for publication on September 15, 1999

\begin{abstract}
Supramolecular chemistry deals with the association of several chemical species, in an organized way and according to well defined purposes. Based on a molecular engineering approach, supramolecular structures can be designed from pre-formed building blocks, providing a promising route from chemistry to molecular nanotechnology. New supramolecular systems have been assembled in our laboratory with the use of bridging unities such as tetrapyridylporphyrins, porphyrazines and polypyrazines, connecting transition metal complexes and clusters. These systems display a very exciting electrochemical and catalytic behavior, and interact with DNA, generating ${ }^{1} \mathrm{O}_{2}$ and leading to efficient oxidative clivage for photodynamic terapy applications. Molecular interfaces have been developed, exhibiting photocurrent response in the presence of visible-UV light, and rectifying properties in the presence of electroactive species. Successful applications of the supramolecular species in chemical and bio-sensors have been developed.
\end{abstract}

Key words: supramolecular chemistry, polynuclear complexes, molecular device.

\section{INTRODUCTION}

In 1959, during his classic talk entitled There's plenty of room at the bottom, Richard Feynman addressed a quite challenging question:

- Why cannot we write the entire 24 volumes of the Encyclopedia Brittanica on the head of a pin?

By focusing on the perspectives of manipulating and controlling things on a small scale, Feynman correctly predicted that by the year 2000 the scientists would be seriously involved in turning this task into reality (Crandall 1997). As a matter of fact, in the last forty years, our society has been completely modified by the technology. Machinery precision has increased by more

\footnotetext{
*Invited paper

** Member of the Academia Brasileira de Ciências

E-mail: henetoma@quim.iq.usp.br
} 
than two orders of magnitude, and the progress in high technology has allowed the successive miniaturization of components reducing the tolerances to the sub-micron level. Technology now is entering the nano-dimensional scale (Coombs \& Robinson 1996). Nano-engineered materials are being pursued because of their superior physical properties; while smaller electronic devices allow faster and more powerful processing.

Nanotechnology appears as an emerging field at the present time, but there is little doubt that it will be the dominant technology in the next century. The progress in this field is being achieved in two ways. The engineering approach to nanotechnology, also known as the top-down approach, aims the progressive miniaturization of existing macro and micro-sized systems or devices. The molecular approach, also referred as molecular nanotechnology, is typically bottom-up, aiming to build up nanoscale devices from atoms and molecules. Molecular manufacturing is the key point in this approach, and can be viewed as an extension of chemical synthesis, but incorporating a great degree of positional control. In fact, supported by computer simulations, the bottom-up way represents a molecular engineering approach for nanotechnology. The ultimate goal in this line, as visualized by K. Eric Drexler (Drexler 1986), would be the assembler, a nano-sized molecular machine with the capability to build up any desired molecular structure, including itself. Similar molecular machines are well known in biological systems, allowing, for instance, the replication and repair of DNA, and the synthesis of proteins and complex biomolecules. However, the chemical construction of a molecular assembler seems yet quite far from reality, since atoms can not be positioned at will without combining with each other and producing a wide variety of molecules. For this reason, the supramolecular approach starting from pre-formed molecular building blocks seems more feasible, providing a promising route from chemistry to molecular nanotechnology.

Supramolecular systems are usually viewed as organized entities of higher complexity which result from the association of several chemical species; however, in addition to the structural organization, well defined purposes are also implicit in the supramolecular design. Although the chemistry involved depends on the nature of the associated species, it can go beyond the properties of the isolated components, as a consequence of the specific molecular interactions which control the affinity, organization and cooperation between the partners (Lehn 1988). In this way, the supramolecular approach deals with the relevant aspects of molecular organization, recognition, host-guest interactions, molecular communication and intelligence, translocation and transport, replication and structural assembly. Incorporating these facts, a new conception of materials has arisen in the present decade, as reported by Bruce and O'Hare in 1992 (Bruce \& O'Hare 1992) and more recently compiled in the impressive collection of Comprehensive Supramolecular Chemistry (Atwood et al. 1996). Nanosized and molecular materials can exhibit a wide diversity of electronic and chemical properties, e.g., piezoelectricity, conductivity, ferroelectricity, ferromagnetism, second and third order polarizabilities, molecular recognition, photophysical, photochemical, catalytic and electrocatalytic activity. In this way, they can be employed in unlimited number of electronic devices and technological applications, as exemplified in Figure 1. 


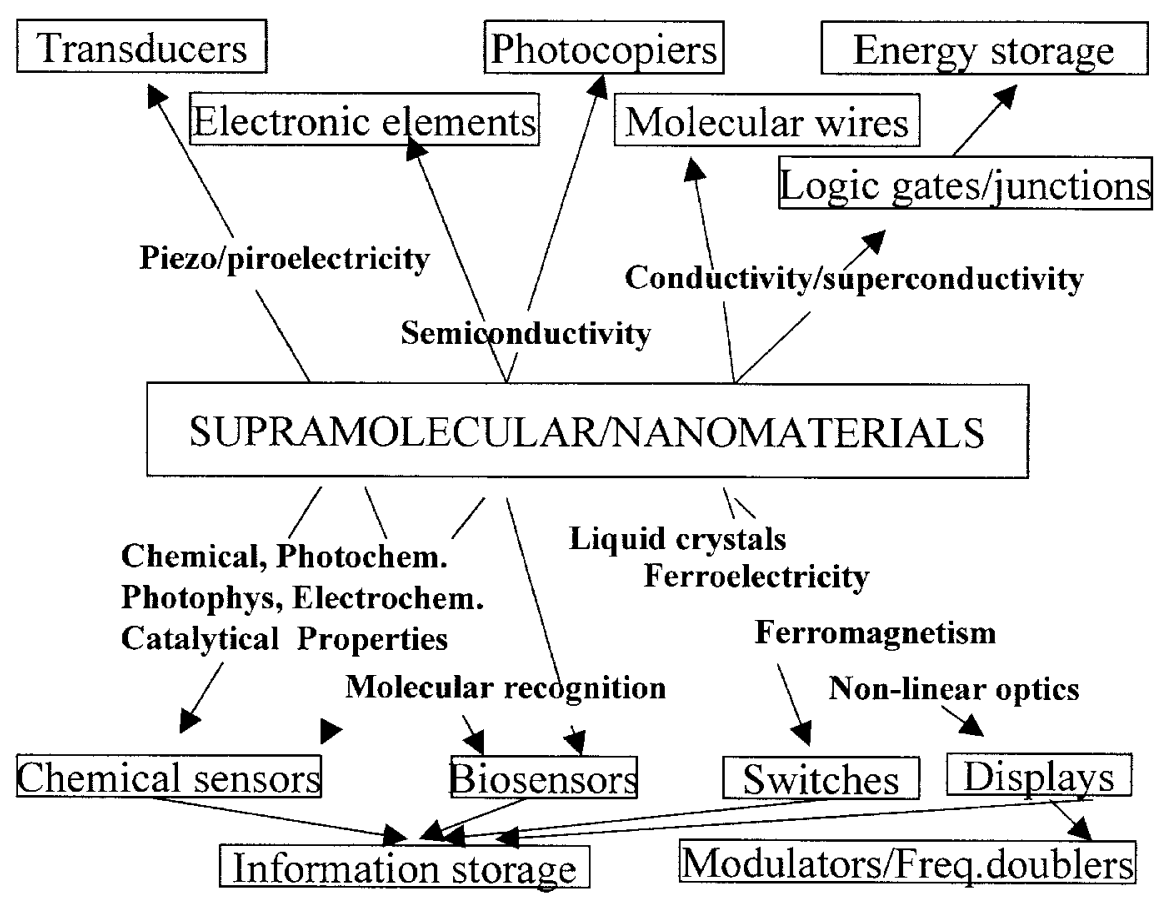

Fig. 1 - Properties and technological applications of supramolecular and nanomaterials.

A great variety of supramolecular systems has been reported in the literature (Atwood et al. 1996, Lehn 1995) from molecular engineered macrocyclic and macropolycyclic compounds, catenanes, rotaxanes, and dendrimers, to self-organized structures and multicomponent self-assembled materials. In addition, there is a special interest in intercalation chemistry, since it is related to supramolecular organization and is frequently employed in the design of nanocomposite materials and catalysts. Organized structures and self-assembly also cover a wide area, as exemplified by molecular films, membranes and liposomes, including polymeric supramolecular systems and supramolecular arrays, ladders and grids based on metal-complexes.

In the present article, we will focus on the typical supramolecular systems which have been assembled in our laboratory, with the use of multibridging metal-organic compounds as molecular building blocks (Toma 1991). The experimental design employed resembles a self-assembly approach directed by the metal-ligand affinities and substitution properties. In the last decade, our efforts have been devoted to three major aspects: a) synthesis of precursor complexes and build up of supramolecular assemblies, b) investigation of relevant physico-chemical properties and reactivity, c) development of molecular interfaces for applications in electronic and analytical devices. Typical systems studied by our group are constituted by substituted porphyrin and phtalocyanines, transition metal polyimine, polypyridine and polypyrazine complexes, and on polynuclear ruthenium-acetate clusters, as molecular building blocks (Figure 2). 
a)

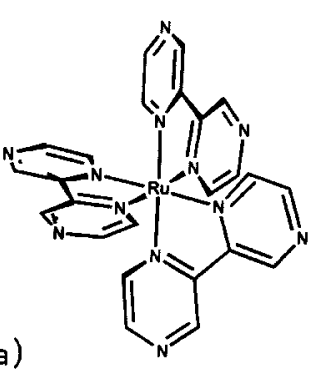

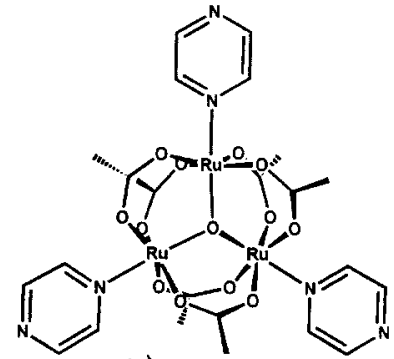

b)
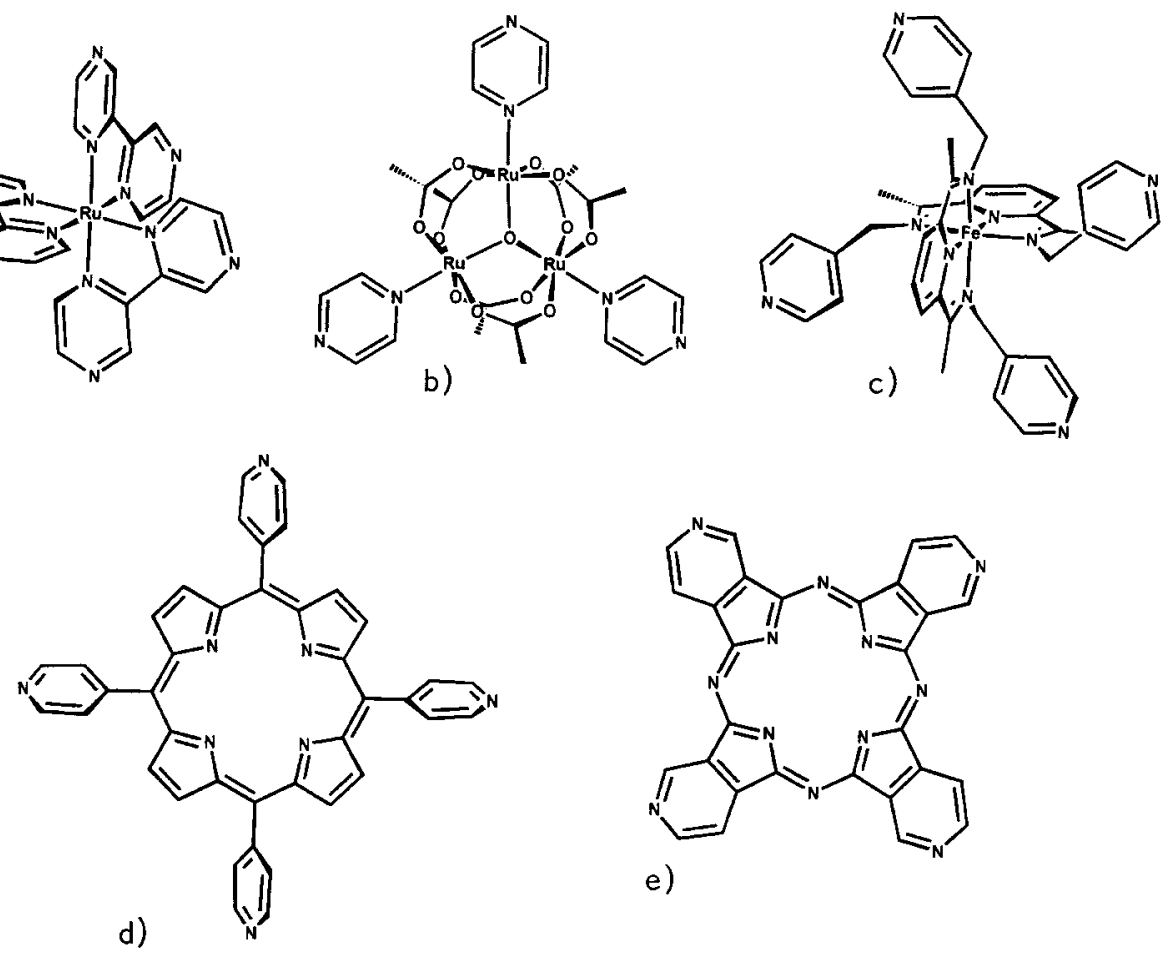

e)

Fig. $\quad 2$ - Typical metal-organic building blocks: a) $\left[\mathrm{Ru}(\mathrm{bpz})_{3}\right]^{2+}$ complex (bpz $=2,2$ '-bipyrazine); b) $\left[\mathrm{Ru}_{3} \mathrm{O}\left(\mathrm{CH}_{3} \mathrm{CO}_{2}\right)_{6}(\mathrm{pz})_{3}\right]^{+}$cluster $(\mathrm{pz}=$ pyrazine); c) ruthenium(II) polyimine complex derived from 2,6diacetylpyridine and 4-methylpyridine; d) meso-tetrapyridylporphyrin; e) tetrapyridylporphyrazine.

\section{Polymetallic Bipyrazine and Polyimine Complexes}

Transition metal polypyridine complexes have been extensively investigated from the perspectives of developing useful supramolecular devices, exploiting their remarkable chemical and photochemical properties (Bignozzi et al. 1997, Balzani et al. 1996, Kohle et al. 1996, Sauvage et al. 1994). A particularly interesting system, is the tris(bipyrazine)ruthenium(II) complex, $\left[\mathrm{Ru}(\mathrm{bpz})_{3}\right]^{2+}$. This complex can be excited at the metal-to-ligand charge-transfer bands (MLCT), yielding a singlet state which is rapidly converted to the ${ }^{3}$ MLCT state. In the excited state, the complex becomes simultaneously a strong oxidizing and reducing species, acting as a good photocatalyst.

An important feature of the bipyrazine complex is the existence of six peripheral uncoordinated nitrogen atoms, available for coupling substrates in energy-transfer or electron-transfer processes. In 1986 we reported that the binding of transition metal complexes to the $\left[\mathrm{Ru}(\mathrm{bpz})_{3}\right]^{2+}$ ion leads to symmetric heptanuclear complexes (Toma \& Sernaglia 1993, Toma \& Lever 1986, Toma et al. 1987, Toma et al. 1988b) of the type $\left[\mathrm{Ru}(\mathrm{bpz})_{3}\left\{\mathrm{ML}_{\mathrm{x}}\right\}_{6}\right]^{\mathrm{n}}$ as shown in Fig. 3. The metal complexes employed were low spin, $3 \mathrm{~d}^{6}$ species, e.g., $\left[\mathrm{Fe}(\mathrm{CN})_{5} \mathrm{H}_{2} \mathrm{O}\right]^{3-},\left[\mathrm{Ru}\left(\mathrm{NH}_{3}\right)_{5} \mathrm{H}_{2} \mathrm{O}\right]^{2+}$ and $\left[\mathrm{Ru}^{\mathrm{II}}(\text { edta }) \mathrm{H}_{2} \mathrm{O}\right]^{2-}$, exhibiting strong affinity for electron-acceptor ligands, such as pyrazine and 
bipyrazine. The self-assembly reaction can be monitored by the rise of characteristic $\mathrm{M} \rightarrow \mathrm{bpz}$ * charge-transfer bands around $700 \mathrm{~nm}$, and by NMR spectroscopy.

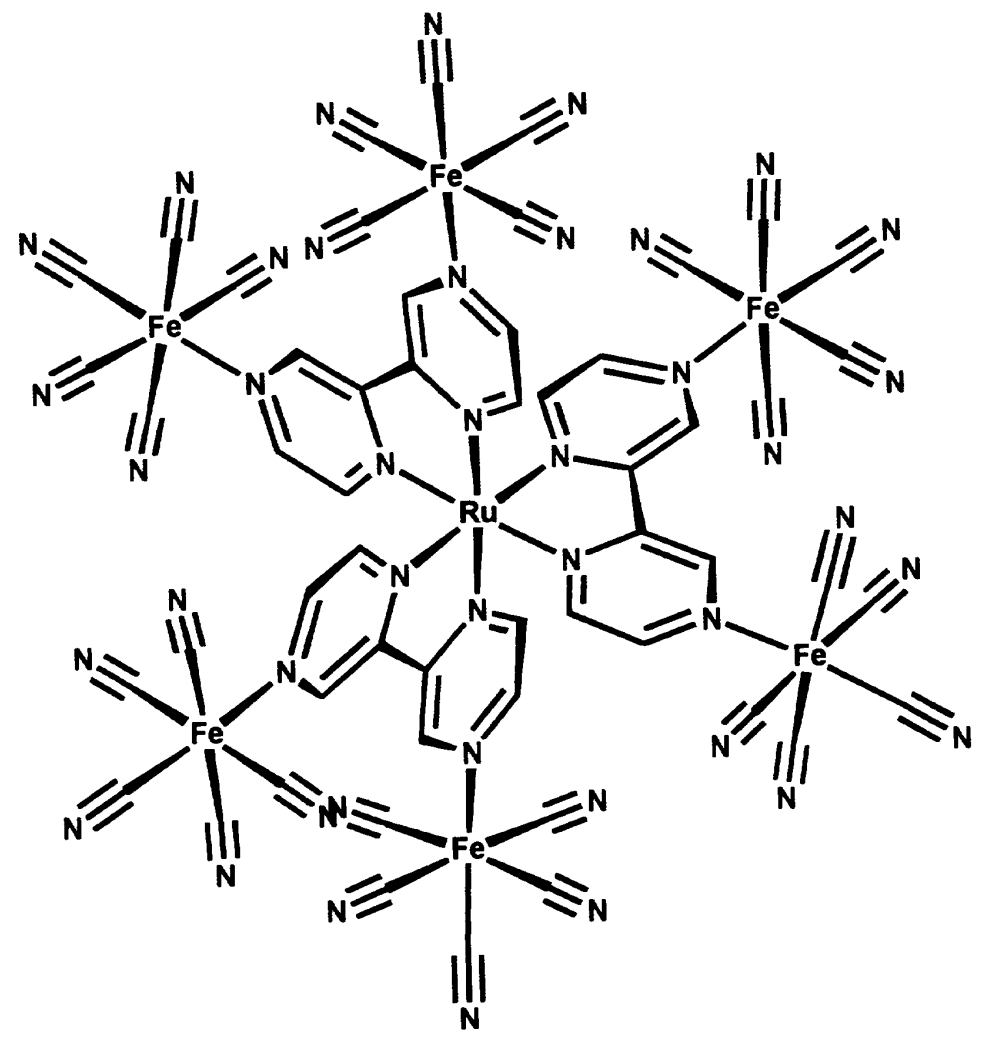

Fig. 3 - Structural representation of the $\left[\mathrm{Ru}(\mathrm{bpz})_{3}\left\{\mathrm{Fe}(\mathrm{CN})_{5}\right\}_{6}\right]^{16-}$ complex.

In the polymetallic system, the $\mathrm{ML}_{\mathrm{x}}$ groups can be reversibly oxidized in aqueous solution, at $\mathrm{E}^{\mathrm{o}}=0.70,0.69$, and $0.38 \mathrm{~V}$, respectively, for the

$$
\left[\mathrm{Fe}(\mathrm{CN})_{5}\right]^{2-/ 3-}, \quad\left[\mathrm{Ru}\left(\mathrm{NH}_{3}\right)_{5}\right]^{3+/ 2+}, \quad \text { and } \quad[\mathrm{Ru}(\text { edta })]^{-/ 2-}
$$

species. In contrast, the central $\left[\mathrm{Ru}(\mathrm{bpz})_{3}\right]^{+}$species exhibits $\mathrm{E}^{\mathrm{O}}\left(\mathrm{Ru}^{\mathrm{III} / \mathrm{II}}\right)=2.08 \mathrm{~V}$, and its oxidation is not feasible in aqueous solution. Photoexcitation in aqueous and organic solvents leads to a complete quenching of the luminescence of the $\left[\mathrm{Ru}(\mathrm{bpz})_{3}\right]^{2+}$ chromophore by the peripheral metal complexes, via intramolecular electron transfer in the excited state:

$$
\begin{aligned}
{\left[\mathrm{Ru}_{\mathrm{c}}{ }^{\mathrm{II}}(\mathrm{bpz})_{3}\left\{\mathrm{M}_{\mathrm{p}}{ }^{\mathrm{II}} \mathrm{L}_{\mathrm{x}}\right\}_{\mathrm{n}}\right]+\mathrm{h} v } & \rightarrow\left[\mathrm{Ru}_{\mathrm{c}}{ }^{\mathrm{III}}\left(\mathrm{bpz}^{-}\right)_{3}\left\{\mathrm{M}_{\mathrm{p}}{ }^{\mathrm{II}} \mathrm{L}_{\mathrm{x}}\right\}_{\mathrm{n}}\right]^{*} \\
{\left.\left[\mathrm{Ru}_{\mathrm{c}}{ }^{\mathrm{III}}(\mathrm{bpz})^{-}\right)_{3}\left\{\mathrm{M}_{\mathrm{p}}{ }^{\mathrm{II}} \mathrm{L}_{\mathrm{x}}\right\}_{\mathrm{n}}\right]^{*} } & \left.\rightarrow\left[\mathrm{Ru}_{\mathrm{c}}{ }^{\mathrm{II}}(\mathrm{bpz})^{-}\right)_{3}\left\{\mathrm{M}_{\mathrm{p}}{ }^{\mathrm{III}} \mathrm{L}_{\mathrm{x}}\right\}_{\mathrm{n}}\right] \\
{\left.\left[\mathrm{Ru}_{\mathrm{c}}{ }^{\mathrm{II}}(\mathrm{bpz})^{-}\right)_{3}\left\{\mathrm{M}_{\mathrm{p}}{ }^{\mathrm{III}} \mathrm{L}_{\mathrm{x}}\right\}_{\mathrm{n}}\right] } & \rightarrow\left[\mathrm{Ru}_{\mathrm{c}}{ }^{\mathrm{II}}(\mathrm{bpz})_{3}\left\{\mathrm{M}_{\mathrm{p}}{ }^{\mathrm{II}} \mathrm{L}_{\mathrm{x}}\right\}_{\mathrm{n}}\right]+\text { heat }
\end{aligned}
$$

Resonance Raman measurements (Toma et al. 1988b, Toma \& Sernaglia 1993) for the

$$
\left[\mathrm{Ru}_{\mathrm{c}}{ }_{\mathrm{c}}^{\mathrm{II}}(\mathrm{bpz})_{3}\left\{\mathrm{Ru}^{\mathrm{II}}\left(\mathrm{NH}_{3}\right)_{5}\right\}_{6}\right]^{14+} \text { and } \quad\left[\mathrm{Ru}_{\mathrm{c}}{ }^{\mathrm{II}}(\mathrm{bpz})_{3}\left\{\mathrm{Ru}^{\mathrm{II}}(\mathrm{edta})_{6}\right]^{10-}\right.
$$


species have indicated a selective enhancement of the $\mathrm{Ru}_{\mathrm{c}}{ }^{\mathrm{II}}$-bipyrazine vibrational peaks according to two distinct patterns for the MLCT bands around 670 and $490 \mathrm{~nm}$. Excitation at the $670 \mathrm{~nm}$ band leads to the enhancement of the totally symmetric vibrational modes of bipyrazine, while only a few vibrational peaks, e.g. at 1470 and $1305 \mathrm{~cm}^{-1}$, of $b_{2}$ symmetry, are selectively enhanced at $490 \mathrm{~nm}$. A vibronic coupling mechanism involving two excited states has been suggested for the excitation at $490 \mathrm{~nm}$.

Recently, we reported the synthesis and characterization of a novel polymetallic supermolecule containing four ruthenium(II)-bipyridine complexes attached to the pendant pyridine residues of an iron(II) polyimine compound (Fig. 4) (Toma \& ChavezGil 1997). This species exhibits the characteristic MLCT bands of the iron(II)-polyimine and Ru(II)-bipy chromophores at 584 and $486 \mathrm{~nm}$, respectively, and an emission band at $614 \mathrm{~nm}$ ascribed to the decay of the lowest ${ }^{3}$ MLCT state in the $\left[\mathrm{Ru}(\text { bipy })_{2} \mathrm{Cl}\right]^{+}$group. Based on cyclic voltammetry and spectroelectrochemical measurements, the potentials of the $\mathrm{Ru}^{\mathrm{III} / \mathrm{II}}$ and $\mathrm{Fe}^{\mathrm{III} / \mathrm{II}}$ redox couples have been estimated at 1.0 and $1.3 \mathrm{~V}$, respectively. A series of reduction waves has been observed below $-0.8 \mathrm{~V}$, and ascribed to the successive reduction of the polyimine ligand, generating an iron(II)-diimine product.

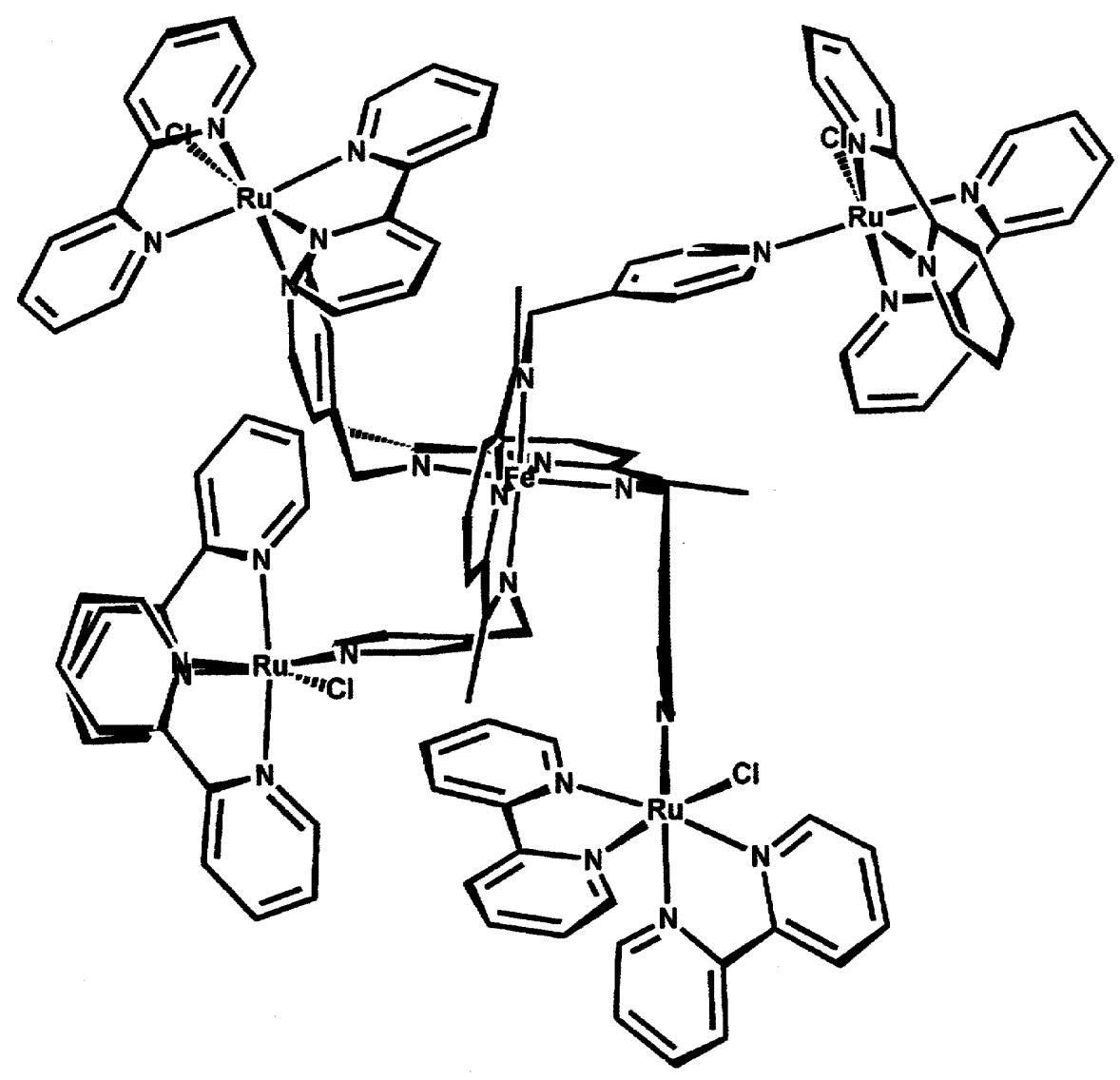

Fig. 4 - Structural representation of the $\left[\mathrm{Fe}(\text { polyimine })\left\{\mathrm{Ru}(\text { bipy })_{2} \mathrm{Cl}\right\}_{4}\right]^{6+}$ complex. 


\section{Polymetallic Clusters}

Ruthenium clusters of the type $\left[\mathrm{Ru}_{3} \mathrm{O}\left(\mathrm{OOCCH}_{3}\right)_{6} \mathrm{~L}_{3}\right]$ are of great interest because of their extensive redox and mixed valence properties (Spencer \& Wilkinson 1972, Baumann et al. 1978, Toma et al. 1988a, Toma \& Cipriano 1989a,b, Toma \& Cunha 1989). These clusters exhibit a triangular structure strongly held by acetate and $\mu$-oxo-bridges, as well as by metal-metal bonds. The electronic spectra of the trinuclear clusters consist of a broad absorption band in the visible near-infrared region, ascribed to metal-metal transitions within the $\mathrm{Ru}_{3} \mathrm{O}$ chromophore, and of a ligand sensitive band in the visible- $\mathrm{uV}$ region, associated with a metal-to-ligand charge transfer transition. The electronic structure of the cluster is strongly based on the $\mathrm{Ru}_{3} \mathrm{O}$ unity, where the central oxygen atom is $\mathrm{sp}^{2}$ hybridized, leaving a single $\mathrm{p}$ orbital to interact with the $\mathrm{d}_{\mathrm{yz}}$ orbitals of the three ruthenium ions. Metal-metal interactions involving the $\operatorname{Ru}\left(d_{y z}\right)-\operatorname{Ru}\left(d_{y z}\right)$ and $\operatorname{Ru}\left(d_{x z}\right)$ $-\mathrm{Ru}\left(\mathrm{d}_{\mathrm{xz}}\right)$ orbitals also play a relevant role in the electronic structure of this type of cluster.

Supramolecular clusters can be assembled by the use of bridging ligands such as pyrazine and 4,4'bipiridine. The binding of transition metal complexes, such as $\left[\mathrm{Ru}\left(\mathrm{NH}_{3}\right)_{5}\right]^{2+},[\mathrm{Ru}(\mathrm{edta})]^{2-}$ and $\left[\mathrm{Fe}(\mathrm{CN})_{5}\right]^{3-}$, to the pyrazine bridging ligand proceeds readily in aqueous solution, leading to bathochromic shifts in the intra-cluster and MLCT bands (Toma et al. 1993, Toma \& Olive 1994).

Recently, extended clusters (Figure 5) have been obtained by the reaction of a symmetric $\left[\mathrm{Ru}_{3} \mathrm{O}\left(\mathrm{OOCCH}_{3}\right)_{6} \mathrm{~L}_{3}\right]^{+}$cluster containing a bridging ligand $(\mathrm{L}=$ pyrazine, or 4,4 'bipyridine $)$ with $\left[\mathrm{Ru}_{3} \mathrm{O}\left(\mathrm{OOCCH}_{3}\right)_{6}(\mathrm{py})_{2}(\mathrm{MeOH})\right]^{+}$as terminal groups (py = pyridine)(Toma \& Alexiou 1995a,b). The electronic properties of the extended clusters are similar to those of the isolated unities, reflecting a relatively weak coupling of the metal centers through the bridging ligand. However, the NMR spectra are quite sensitive to the changes of symmetry, as well as in the molecular environment, being a suitable technique for the investigation of this type of extended cluster.

\section{Polymetallic Porphyrins and Porphyrazines}

Porphyrins are important prostetic groups of a number of metalloproteins and enzymes, and their function depend on the nature of the axial ligands as well as on the specific environment provided by the polypeptide chain. They are very interesting species for the assembly of supramolecular structures, because of their symmetric structure and suitable chemical, photochemical and photophysical properties for applications in catalysis, artificial photosynthesis and molecular devices (Krishnamohan-Sharma et al. 1999, Nakano et al. 1998, Gust et al. 1994).

Modified porphyrins containing transition metal complexes attached to peripheral pyridine groups have been extensively investigated in our laboratory in the last ten years. In 1988 we reported a new type of modified porphyrin containing $\left[\mathrm{Ru}\left(\mathrm{NH}_{3}\right)_{5}\right]^{2+}$ groups attached to the peripheral pyridine residues of meso-tetrapyridylporphyrin (TPyP) (Toma \& Araki 1988). A similar species, containing four $\left[\mathrm{Ru}^{\mathrm{III}}(\text { edta) }]^{-}\right.$groups was reported later, i.e., $\left[\mathrm{MTPyP}\left\{\mathrm{Ru}^{\mathrm{III}}(\text { edta) }\}_{4}\right]^{4-}\right.$, (Figure 6) exhibiting enhanced electrocatalytical activity in the four electron reduction of molecular oxygen 


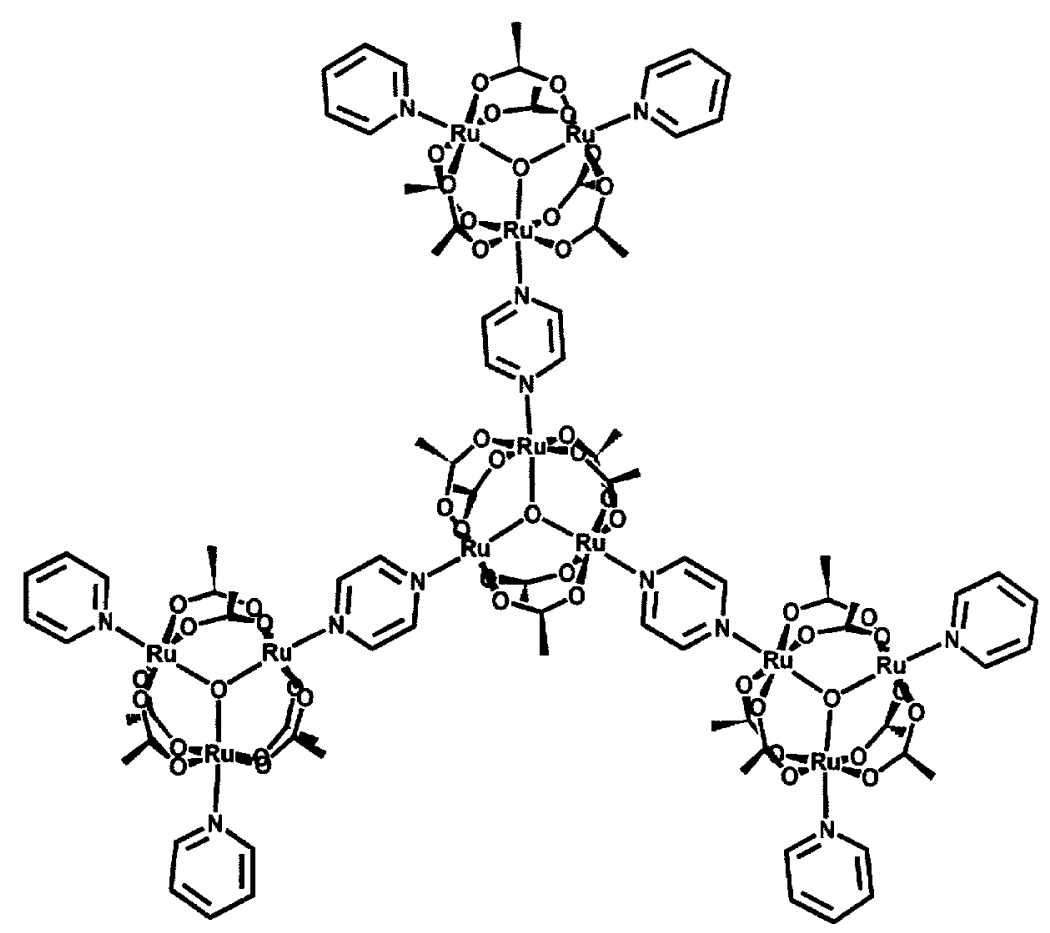

Fig. 5 - Structural representation of a supramolecular cluster.

(Toma \& Araki 1990, Araki \& Toma 1991a,b). Anson et al., observed that the $\left[\mathrm{Ru}\left(\mathrm{NH}_{3}\right)_{5}\right]^{2+}$ modified cobaltporphyrin, exhibit pronounced electrocatalytical activity in $\mathrm{O}_{2}$ reduction (Anson $e t$ al. 1997).

A particularly interesting series of supramolecular metalloporphyrins has been obtained from meso-tetrapyridylporphyrin by using $\left[\mathrm{Ru}(\text { bipy })_{2} \mathrm{Cl}\right]^{+}$groups as modifiers (Araki \& Toma 1993, Araki et al. 1993, Araki \& Toma 1994a, Araki et al. 1995a,b,c). The

$\mu$-(meso-5,10,15,20-tetra(pyridyl)porphyrin \}tetrakis(bis(bipyridine) (chloride) ruthenium(II)\} complex, $\left[\mathrm{TPyP}\left\{\mathrm{Ru} \text { (bipy) }{ }_{2} \mathrm{Cl}\right\}_{4}\right]^{4+}$ (Figure 7) is a prototype of a series, containing photochemically and electrochemically active groups directly attached to the porphyrin system.

The electronic spectra show the characteristic Soret band at $418 \mathrm{~nm}$ and the $\beta$ and $\alpha$ doublets of the porphyrin at 518, 558 and 594, $650 \mathrm{~nm}$, respectively, in addition to the absorption bands of the $\left[\mathrm{Ru}(\text { bipy })_{2} \mathrm{Cl}\right]^{+}$moieties at $298 \mathrm{~nm}$ (bipy $\left.\pi \rightarrow \pi^{*}\right)$ and $470 \mathrm{~nm}\left(\mathrm{Ru}^{\mathrm{II}} \rightarrow\right.$ bipy chargetransfer). The complex emits at 655 and $700 \mathrm{~nm}$ (shoulder), when excited at the porphyrin or $\left[\mathrm{Ru} \text { (bipy) }{ }_{2} \mathrm{Cl}\right]^{+}$absorption bands. The emission energies are similar to those observed for (tetra$\mathrm{N}$-methylpyridinium)porphyrin and can be ascribed to the decay of the low lying singlet $\pi^{*}$-excited states of the porphyrin center. The excitation spectrum reproduces the absorption spectrum of the tetraruthenated porphyrin, even in the region of the $\left[\mathrm{Ru}\left(\text { bipy }{ }_{2} \mathrm{Cl}\right]^{+}\right.$chromophore. Therefore, the $\pi^{*}$ emitting state can be pumped either from a direct excitation at the porphyrin center, or by 


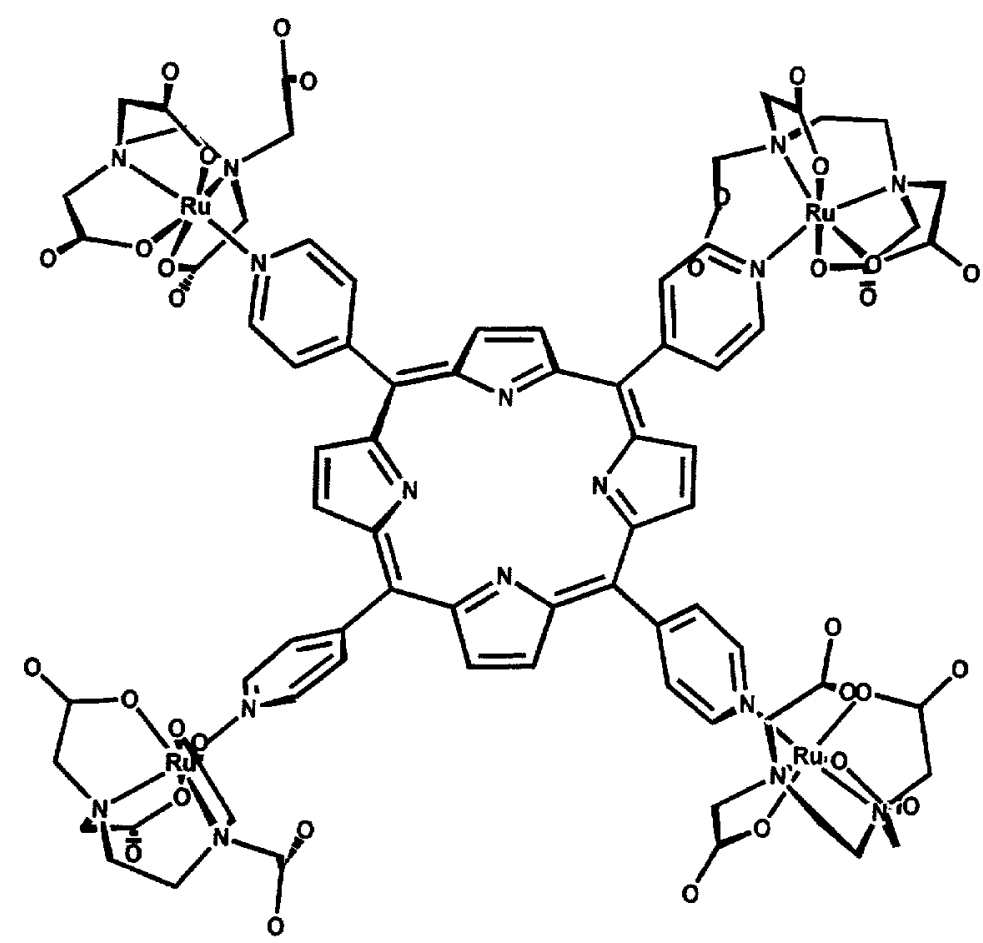

Fig. 6 - Structural representation of the polymetallic porphyrin $\left[\operatorname{MTPyP}\left\{\operatorname{Ru}(\text { edta })_{4}\right]^{n+}\right.$.

an intramolecular mechanism involving the peripheral ruthenium complexes. Below $\mathrm{pH} \mathrm{3,} \mathrm{the}$ modified porphyrin can be reversibly protonated at the pyrrole $\mathrm{N}$-atoms, shifting the Soret band from $414 \mathrm{~nm}$ to $440 \mathrm{~nm}$. The electronic bands of the peripheral ruthenium complexes remain practically unchanged; however, a new intense band appears around $690 \mathrm{~nm}$. This band decays when the metal ions are oxidized, or when the porphyrin is reduced, indicating a ruthenium(II)-toprotonated porphyrin charge-transfer transition.

Cyclic voltammograms of the tetraruthenated porphyrin $\left[\mathrm{TPyP}\left\{\mathrm{Ru}(\text { bipy })_{2} \mathrm{Cl}\right\}_{4}\right]^{4+}$ species exhibit reversible waves at $0.92,-0.68$ and $-0.93 \mathrm{~V}$, the first one being four times more intense than the other two. According to the spectroelectrochemical measurements, the redox process at 0.92 $\mathrm{V}$ leads to reversible changes in the absorption bands at $470 \mathrm{~nm}$ and $298 \mathrm{~nm}$, associated with the MLCT and $\pi \rightarrow \pi^{*}$ bands in the $\left[\mathrm{Ru}(\text { bipy })_{2} \mathrm{Cl}\right]^{+}$chromophore. The oxidation of the ruthenium complexes leads to a $30 \%$ decay in the intensity of the Soret band, which is shifted from 418 to $424 \mathrm{~nm}$, reflecting the perturbation of the electronic levels of TPyP by the ruthenium complexes. The spectroelectrochemical behavior at -0.68 and $-0.93 \mathrm{~V}$ is similar to that observed for the tetramethylated porphyrin, showing a complete decay of the Soret band, consistent with two successive monoelectronic redox processes at the porphyrin ring.

The $\left[\mathrm{ZnTPyP}\left\{\mathrm{Ru}\left(\text { bipy) }{ }_{2} \mathrm{Cl}\right]_{4}\right]^{4+}\right.$ complex (Araki \& Toma 1994b) exhibits the characteristic absorption bands of $\mathrm{Zn}^{\mathrm{II}} \mathrm{TPyP}$ at $430 \mathrm{~nm}$ (Soret band), 562 and $606 \mathrm{~nm}$ (Q bands), and of the 


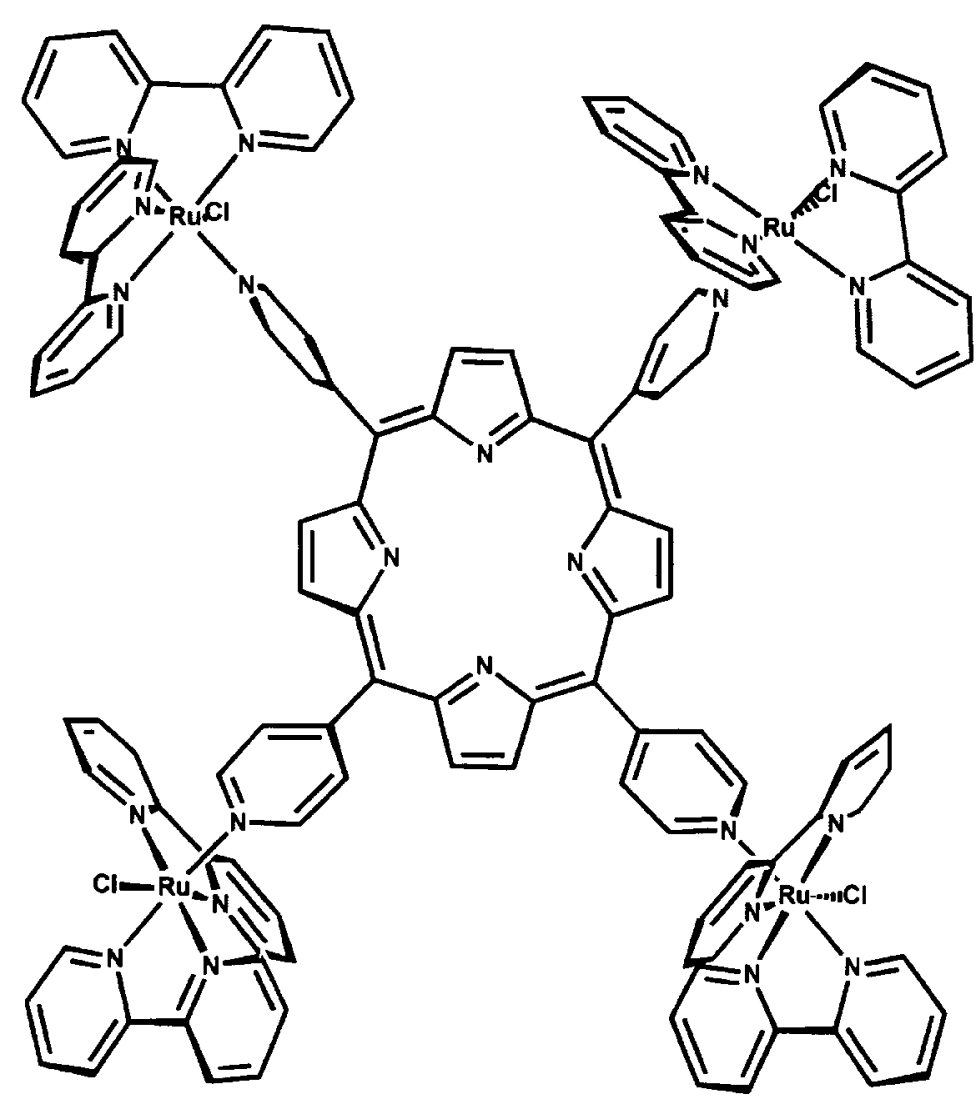

Fig. 7 - Structural representation of $\left[\mathrm{TPyP}\left\{\mathrm{Ru}(\text { bipy })_{2} \mathrm{Cl}\right\}_{4}\right]^{4+}$.

$\left[\mathrm{Ru}^{\mathrm{II}}\left(\text { bipy) }{ }_{2} \mathrm{Cl}\right]^{+}\right.$moities at $298 \mathrm{~nm}$ (bipy, $\left.\pi \rightarrow \pi^{*}\right)$, 450-490 nm (Ru ${ }^{\mathrm{II}}$-to-bipy charge transfer envelope) and $358 \mathrm{~nm}$. The complex exhibits two well-defined fluorescence bands at 606 and $655 \mathrm{~nm}$, corresponding to the singlet-singlet $\mathrm{Q}_{00}$ and $\mathrm{Q}_{10}$ transitions of the ZnTPyP group. It should be noted that the excitation spectrum obtained by monitoring the intensity of these two fluorescence bands does not coincide with the absorption spectrum of the tetraruthenated complex, but reproduces very closely the absorption profile of the zinc porphyrin group, represented by the Soret, $\mathrm{Q}_{00}$ and $\mathrm{Q}_{10}$ bands at 417, 554 and $601 \mathrm{~nm}$, respectively. At low temperatures $(77 \mathrm{~K})$, the emission spectrum of the corresponding ethanol glass exhibits narrower $\mathrm{Q}_{00}$ and $\mathrm{Q}_{01}$ bands at 597 and $652 \mathrm{~nm}$, and another band at $770 \mathrm{~nm}$. This new band can be ascribed to the triplet state emission $\left(\mathrm{T}_{00}\right)$ by comparison with the phosphorescence spectrum of similar porphyrins. The excitation spectrum obtained by monitoring the $652 \mathrm{~nm}$ porphyrin triplet emission is similar to that recorded at room temperature; but when the $770 \mathrm{~nm}$ porphyrin triplet emission is monitored, a quite different excitation profile results. In this case, the charge transfer absorptions associated with the peripheral ruthenium complexes also appear around 500 and $450 \mathrm{~nm}$, indicating the occurrence of energy transfer from the $\left[\mathrm{Ru} \text { (bipy) }{ }_{2} \mathrm{Cl}\right]^{+}$triplet states to the lowest energy triplet state of the 
porphyrin. This conclusion is corroborated by the fact that the emission spectrum obtained on excitation at $450 \mathrm{~nm}$, i. e., in the MLCT band of the ruthenium complexes, exhibits essentially the porphyrin phosphorescence emission.

The $\left[\text { NiTPyP }\left\{\mathrm{Ru}(\text { bipy })_{2} \mathrm{Cl}\right\}_{4}\right]^{4+}$ complex exhibits a low spin configuration (Araki \& Toma 1994a, Araki et al. 1995a), and its electronic spectrum composed by the characteristic absorption bands of the ruthenium(II) polypyridine groups at 298, 354 and $490 \mathrm{~nm}$, and by the Soret, $\mathrm{Q}_{10}$ and $\mathrm{Q}_{00}$ bands of the $\mathrm{Ni}$ (II) porphyrin moiety at 414,530 and $580 \mathrm{~nm}$. The cyclic voltammograms of this complex in acetonitrile solutions exhibit a reversible pair of waves at $0.92 \mathrm{~V}$, four times more intense than for a complex exhibiting a single monoelectronic redox center. The voltammetric response is consistent with a polynuclear complex possessing four equivalent, weakly interacting redox sites. A second, irreversible wave is observed at $1.57 \mathrm{~V}$, corresponding to the oxidation of the porphyrin ring. In the cathodic region, two reversible waves are observed at -0.80 and $-0.97 \mathrm{~V}$, associated with the reduction of the porphyrin. At $-1.5 \mathrm{~V}$, an intense wave is observed, consistent with four electron equivalents, involving the reduction of the bipyridine ligand. It should be noticed that the tetraruthenated nickelporphyrin is more difficult to reduce than $[\mathrm{NiTMPyP}]^{4+}(-0.37,-0.73)$, reflecting the influence of the -backbonding interactions from the attached $\mathrm{Ru}^{\mathrm{II}}$ groups.

In order to evaluate the existence of $\mathrm{Ni}(\mathrm{I})$ character in the reduced complexes generated at -0.80 $\mathrm{V}$, the electrochemical behavior in the presence of methyl iodide was investigated. $\mathrm{Ni}(\mathrm{I})$ species, exhibiting a $\mathrm{d}^{9}$ configuration, and $\mathrm{CH}_{3}$ radical are isolobal species, and should react readily, in contrast to the $\mathrm{Ni}$ (II) species. As a matter of fact, methyl iodide enhances by a factor of 2, the cathodic current at $-0.80 \mathrm{~V}$. No effect is observed when the porphyrin anion presents essentially a $\pi$-radical character. Therefore, the results indicate a significant $\mathrm{Ni}(\mathrm{I})$ character for the reduced tetraruthenated porphyrin species. In the presence of $\mathrm{CO}_{2}$, there is a small increase in the reduction wave at $-0.80 \mathrm{~V}$, and a great increase at $-1.30 \mathrm{~V}$, just preceding the reduction wave of the coordinated bipyridine ligands at $-1.4 \mathrm{~V}$. According to the voltammograms, the major products of the reduction of $\mathrm{CO}_{2}$ are electrochemically inactive in the range of -1.5 to $1.0 \mathrm{~V}$, and the most probable species is $\mathrm{CO}$, in analogy to several related studies in non-aqueous media. The peripheral $\left[\mathrm{Ru}(\mathrm{bipy})_{2} \mathrm{Cl}\right]^{+}$ groups probably enhance the catalytic activity of the nickel porphyrin center, by improving the electron donor properties and the $\mathrm{Ni}(\mathrm{I})$ character of the reduced species.

In order to exploit the redox catalytic properties of the porphyrins, a novel supramolecular species has been designed (Toma et al. 1998), incorporating four trinuclear ruthenium clusters, as shown in Figure 8.

In this prototype species, the characteristic electronic and redox properties of the porphyrin and cluster moieties are preserved, allowing the selective tuning of five redox states of the trinuclear ruthenium centers in addition to the porphyrin oxidized and reduced states. The inclusion of manganese ions into the porphyrin ring gives rise to a powerful cytochrome P-450 type catalyst, enabling the selective oxidation of cyclohexane to the corresponding alcohol species.

Another related family of supramolecular species is based on the polymetallation of tetra- 


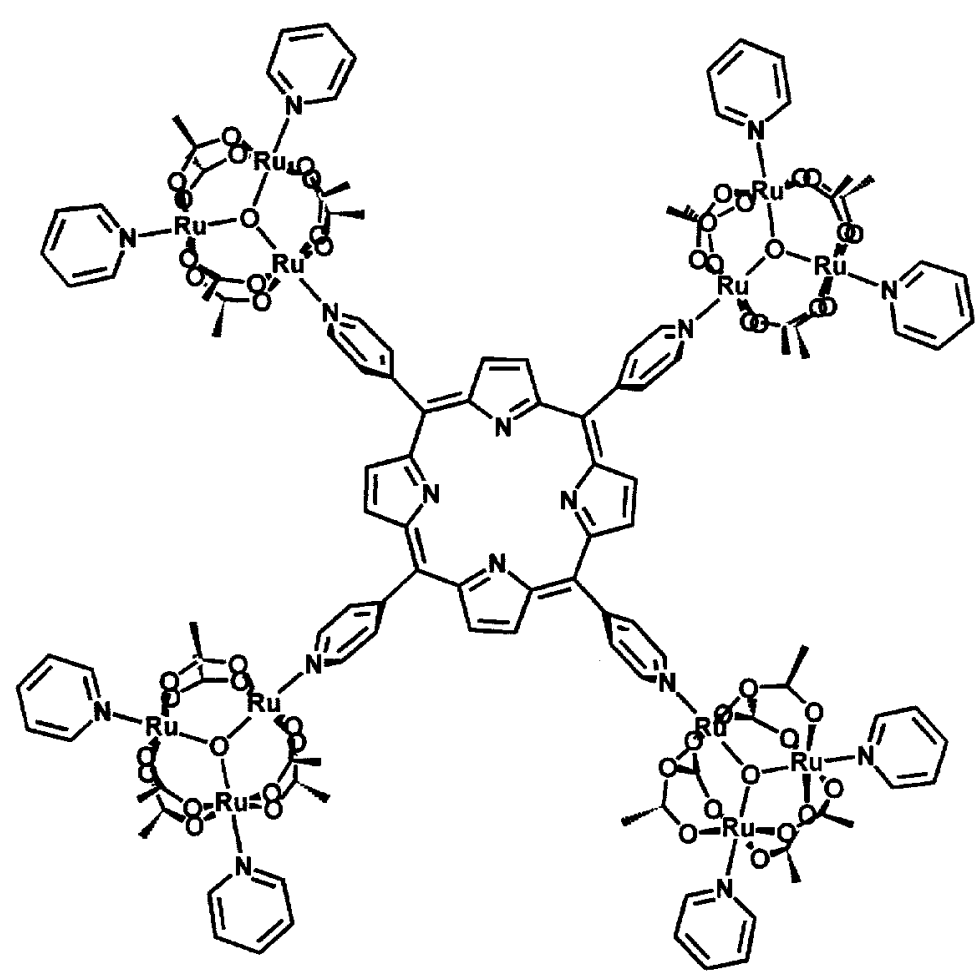

Fig. 8 - Structural representation of a dodecanuclear cluster-porphyrin supermolecule.

pyridylporphyrazine species, which belong to the phtalocyanine series (Toyama et al. 1998a, b). Tetra(3-pyridyl)porphyrazine has been modified with four peripheral $\left[\mathrm{Ru}(\text { bipy })_{2} \mathrm{Cl}\right]^{+}$groups, yielding a dark green tetraruthenated species (Figure 9). In contrast to the porphyrin analogues, the spectroscopic and electrochemical properties of the tetraruthenated porphyrazine center have indicated a significant electronic interaction between the central and peripheral groups. In addition, fluorescence emission from the porphyrazine core has been observed at room temperature, either by direct excitation at the Soret and Q bands, or by excitation at the peripheral ruthenium-bipyridine complexes, evidencing an efficient antenna effect. The efficient generation of singlet oxygen species from the porphyrazine excited triplet states has also been reported.

\section{DNA Interaction and Photoinduced Oxidations Mediated by}

\section{SUPRAMOLECULAR PORPHYRINS}

The interaction of photosensitizing compounds with biological macromolecules has been extensively investigated in recent years in connection with relevant photodynamic therapy (PDT) applications (Dougherty et al. 1998). PDT involves the use of light to sensitize photoactive species in order to promote electron transfer or hydrogen abstraction reactions, or to induce oxidation reactions via the formation of singlet oxygen species.

A systematic study involving tetraruthenated porphyrin and DNA or 2'-deoxyguanosine bases 


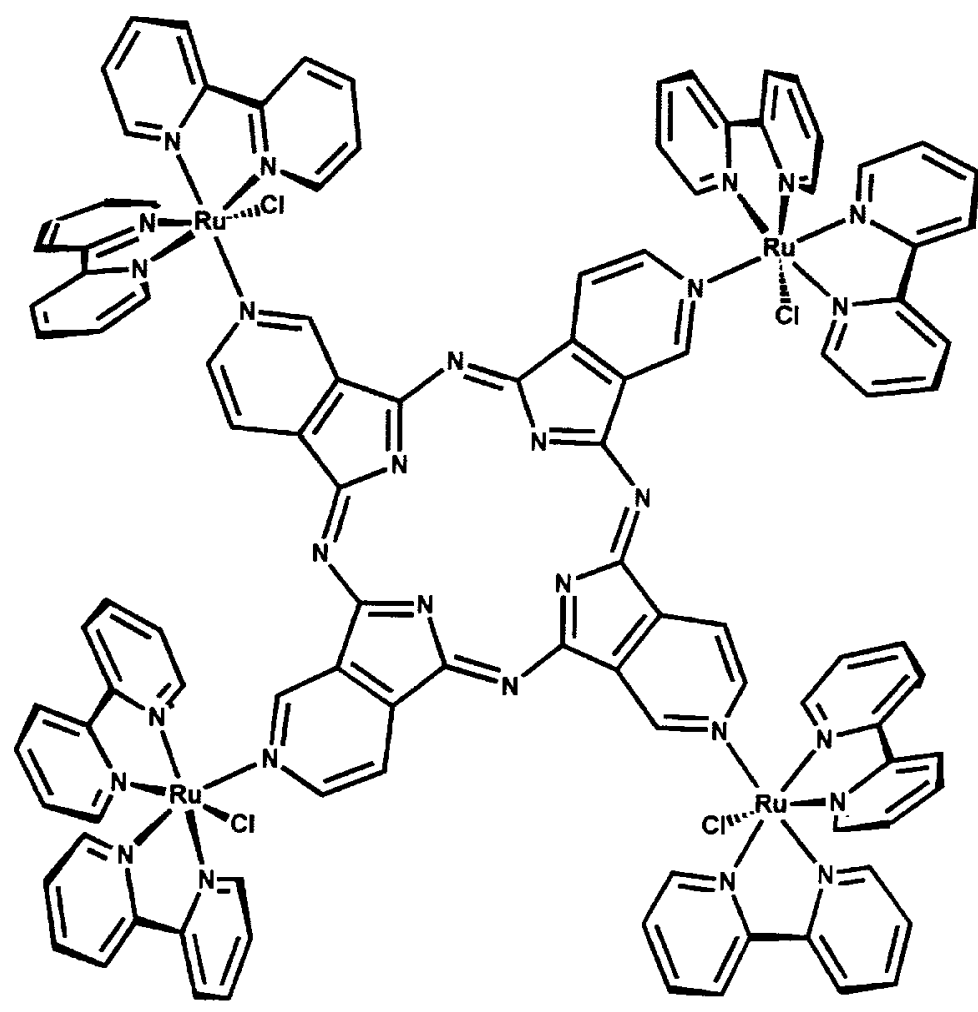

Fig. 9 - Structural representation of a tetraruthenated porphyrazine species.

has been carried out in our laboratory (Ravanat et al. 1998, Onuki et al. 1996). Direct fluorescence and electronic absorption measurements after incubation of the modified porphyrin and DNA have indicated strong binding between pBR322 DNA or calf thymus DNA with the modified porphyrin. It has been shown that the exposure of pBr322 DNA to light, in the presence of the tetraruthenated porphyrin leads to single-strand break formation, as determined by the conversion of the supercoiled form of the plasmid into the circular form. In addition, oxidative DNA base damage has been evaluated by the detection of 8-oxo-7,8-dihydro-2'deoxyguanosine, after irradiation of calf thymus DNA in the presence of the modified porphyrin. The results are consistent with the specificity of the binding mode, and the predominance of the mechanism involving singlet oxygen in the photooxidation mediated by the tetraruthenated porphyrins. Indeed, singlet molecular oxygen formation, after TRP excitation, has been confirmed by monitoring its characteristic near-infrared emission.

\section{Developing Molecular Interfaces}

Technological applications of molecular and supramolecular systems will depend on their efficient communication with the interfaces employed in the instruments and devices; e.g. conducting surfaces, optical fibers, membranes, etc. For instance, redox enzymes have been successfully 
employed in sensor devices, after the discovery of suitable molecular wires which act as interfaces, conducting the electrons to the detector (Aizawa 1994). On the other hand, immobilization of redox active species onto electrodes allow their modification, giving rise to a new type of sensorial system incorporating the characteristic properties of the molecular species. Analogously, optodes, i.e. optical sensorial devices, can be obtained by the immobilization of chromophore or luminescent species onto the surface of optical fibers or windows. A number of electrochemical, electronic and photonic devices can be devised, based on the molecular interfaces acting as sensorial elements or tranduscers (Mallouk \& Gavin 1998, Wong 1994) as exemplified in Figure 1.

In our laboratory, the development of molecular interfaces has been conducted in three different ways: a) generation of Prussian blue films, b) self-assembly of molecular films and layers and c) intercalation of molecular species into lamellar, conducting metal-oxide films.

\section{Prussian Blue Films}

Prussian blue, the classical coordination compound $\mathrm{Fe}_{4}\left[\mathrm{Fe}(\mathrm{CN})_{6}\right]_{3}$, exhibits an outstanding performance as electrode modifiers in electrochromic devices (Hartmann \& Grabner 1991). This material form high quality, thin conducting films, exhibiting reversible electrochemical response in addition to a cation selective response (Itaya et al. 1986).

The Prussian blue strategy can be applied to the immobilization of molecular species, after the incorporation of $\left[\mathrm{Fe}(\mathrm{CN})_{5}\right]^{3-}$ residues, using bridging ligands. In this way, the immobilization of the $\left[\mathrm{Ru}_{\mathrm{c}}{ }_{\mathrm{c}} \mathrm{I}(\mathrm{bpz})_{3}\left\{\mathrm{Fe}(\mathrm{CN})_{5}\right\}_{n}\right]^{m-}$ species at electrode surfaces has been carried out successfully (Hidalgo-Luangdilok \& Bocarsly 1990). This film exhibits photocurrent response in the presence of light, following an excitation profile coinciding with the absorption bands of the $\left[\mathrm{Ru}^{\mathrm{II}}(\mathrm{bpz})_{3}\right]^{2+}$ center. The presence of electron donor species, such as dioxygen, is required in order to sustain the photoaction response. A similar strategy has been employed for the immobilization of the trinuclear cluster species onto metallic surfaces (Toma et al. 1993).

\section{Molecular Films}

The $\left.\left[\mathrm{MTPyP}\left\{\mathrm{Ru}(\text { bipy })_{2} \mathrm{Cl}\right\}_{4}\right\}\right]^{n+}$ complexes in the presence of a suitable counter ion, e.g. trifluomethanesulfonate, TFMS, form very homogeneous films onto solid surfaces. The nature of the polymetallic complex is preserved in the adsorbed films, as can be inferred from its characteristic electronic spectrum, resonance Raman and electrochemical response. In the case of the $\left[\mathrm{ZnTPyP}\left\{\mathrm{Ru}(\mathrm{bipy})_{2} \mathrm{Cl}\right\}_{4}\right]^{4+}$ complex (Araki \& Toma 1994b), in contrast with the fluorescence emission observed in solution, the films exhibit only a narrow emission band at $730 \mathrm{~nm}$ (Figure 9), as found in the phosphorescence spectrum in ethanol glass at $77 \mathrm{~K}$. A remarkable point is that no fluorescence emission (only phosphorescence) is observed for the films at room temperature. The excitation profiles parallel the absorption profiles of $\mathrm{ZnTPyP}$ and $\left[\mathrm{Ru}(\mathrm{bipy})_{2} \mathrm{Cl}\right]^{+}$moieties, indicating that the peripheral groups are effectively acting as antennae in the complex. This means that, in contrast with the photophysical behaviour in solution, there is an efficient electronic cou- 
pling between the peripheral and central groups in the films. The electronic coupling facilitates the singlet-triplet conversion, decreasing the fluorescence emission, and promoting a rapid energy transfer from the $\left[\mathrm{Ru}^{*}(\mathrm{bipy})_{2} \mathrm{Cl}\right]^{+}$groups towards the zinc porphyrin moiety, competing with the thermal deactivation processes. Another remarkable aspect associated with the photoactivity of the $\mathrm{ZnTPyP}$ and $\left[\mathrm{Ru}(\text { bipy })_{2} \mathrm{Cl}\right]^{+}$moieties in the films is illustrated by their photoelectrochemical properties. When the films are illuminated in an aqueous solution containing dissolved oxygen and the electrolyte, LiTFMS, a stable photocurrent response is generated, reproducing the absorption profile of the solid tetraruthenated complex. This result confirms that the $\left[\mathrm{Ru}(\mathrm{bipy})_{2} \mathrm{Cl}\right]^{+}$groups can effectively act as antennae, absorbing light and transferring energy or electrons within the molecular framework at the electrode surface. The starting species is regenerated in the presence of dissolved oxygen, in a catalytic manner, so that the process can be repeated indefinitely as long as dioxygen is supplied to the solution.

The electronic spectra of the films of the $\left[\mathrm{Ni}^{\mathrm{iI}} \mathrm{TPyP}\left\{\mathrm{Ru}^{\mathrm{II}}(\mathrm{bipy})_{2} \mathrm{Cl}\right\}_{4}\right](\mathrm{TFMS})_{4}$ species are very similar to those of the molecular species in solution (Araki et al. 1995c) The films deposited on glassy carbon exhibit a well behaved electrochemical response in aqueous solution, displaying reversible waves at $\mathrm{E}^{\mathrm{o}}=0.95 \mathrm{~V}$, associated with the peripheral ruthenium groups (Fig. 10). The peak currents increase linearly as a function of the scan rate, with a small difference in the slopes arising from the non-equivalent FWHM values. These results are consistent with a fast ion diffusion and electron transfer within the film, with a minor repulsive site-to-site interaction, or differences in redox species environment. Because of their bulkiness, the mobility of the molecules within the film should be hindered, and molecular diffusion can not support a direct electron transfer to the electrode. Therefore, the electron transport within the film should occur by self-exchange or electronic conduction mechanisms. In the presence of ferrocyanide ions, no current is observed at the normal oxidation potential, e.g. $0.37 \mathrm{~V}$, during the anodic scan; however, a sharp wave appears at the beginning of the $\mathrm{Ru}^{\mathrm{III} / \mathrm{II}}$ anodic wave $(0.7 \mathrm{~V})$ so that the electronic conduction mechanism can definitely be ruled out. This behavior is identical to that observed in redox polymers bilayers in which the outer film electroactive species have a more negative potential than the inner one, but the electron transfer is mediated by the inner film redox species. Since the outer redox species is in solution, the solvated ferrocyanide ions can neither diffuse through nor exchange with the anions present in the film, because of the compact arrangement of the tetraruthenated nickelporphyrin molecules. Therefore, the electrochemical processes should be mediated by the film, which acts as a conduction gate, allowing an unidirectional electron flow from the solution to the electrode.

The $\left[\mathrm{CoTPyP}\left\{\mathrm{Ru}(\text { bipy })_{2} \mathrm{Cl}\right\}_{4}\right](\mathrm{TFMS})_{5}$ films are particularly suitable electrode modifiers (Araki et al. 1995a, b, Angnes et al. 1996), possessing good homogeneity, stability and adherence. Analogously to the $\mathrm{Ni}^{\mathrm{II}}$ films, the modified electrodes exhibit only one well defined pair of waves at $0.95 \mathrm{~V}$, in aqueous solution, ascribed to the $\mathrm{Ru}^{\mathrm{III} / \mathrm{II}}$ redox couple. The $\mathrm{Co}^{\mathrm{IIII}}$ films were successfully employed in the determination of nitrite, sulfite, NADH and dopamine, in flow analysis (Araki $e t$ al. 1995b, Angnes et al. 1996, Azevedo et al. 1999, Azevedo et al. 1998). The glassy carbon 
electrodes coated with molecular films of the tetraruthenated cobaltporphyrin exhibited enhanced electrochemical response, leading to sharp signals at the onset of the $\mathrm{Ru}^{\mathrm{III} / \mathrm{II}}$ redox wave $(0.70 \mathrm{~V})$. In addition to a higher selectivity for the reduced species in solution, the modified electrodes were not susceptible to surface poisoning, as observed in the case of bare electrodes (for NADH and dopamine).

\section{Vanadium(V) Oxide and Bentonite Intercalated Films}

Vanadium $(\mathrm{V})$ pentoxide films have been extensively investigated in the last decades due to their applications in batteries, as well as, in optical, analytical and electrochromic devices (Livage 1991, Livage 1996) (Anaissi et al. 1999). This type of film admits a number of variations, depending on the starting materials and the treatment applied. A layered material is obtained by the slow evaporation of the vanadium $(\mathrm{V})$ oxide xerogels, at room temperature. The resulting solid is made up of layers of polyvanadate ribbons linked by water molecules and exhibits very interesting electronic and electrochemical properties associated with the occurrence of mixed valence interactions and ionic transport. As a matter of fact, according to Livage (Livage 1996) the layered xerogels exhibit an improved electrochemical behavior in terms of faradaic yields and reversibility.

Intercalation of porphyrin species into vanadium(V) oxide xerogel films has been successfully carried out in our laboratory (Toma et al. 1994) for the preparation of modified electrodes exhibiting selective electrocatalytical behavior. We are now extending the approach to the intercalation of supramolecular species and conducting polymeric films, in order to exploit their possible use in electrochemical and electronic devices. Exciting results are being obtained with a combined material resulting from the interaction of colloidal bentonite and vanadium(V) oxide xerogels (Anaissi et al. 1999). This novel material exhibits a lamellar structure containing vanadium(V) oxide and silicate layers. In contrast to the vanadium-oxide films, the composite xerogels are not soluble in water, displaying enhanced electrochemical signals in the presence of electroactive species such as the hexaammineruthenium(II) complex, as a consequence of their intercalation into the interlamellar space.

\section{FINAL REMARKS}

At the end of this century, supramolecular chemistry appears as a revolutionary way of dealing with chemical compounds and concepts, exploiting the properties beyond the frontiers of the isolated molecules, and combining a wide diversity of chemical species in unusual molecular arrangements. Supramolecular chemistry has already discovered the great possibilities of semiotics and molecular recognition for the design of intelligent molecules and devices. Molecular electronics and photonics are being expected as the next generation of advanced machines, in the same way as supramolecular assembly can allow the production of nanofunctional devices and materials for the outcoming nanotechnological age. 


\section{ACKNOWLEDGEMENTS}

I gratefully acknowledge the kind consideration received from the John Simon Guggenheim Memorial Foundation; and the faculty members, participants and organizers of the Workshop on Supramolecular Chemistry, in special to Profs. José M. Riveros and Koiti Araki, from the University of São Paulo.

\section{REFERENCES}

AIzAWA M 1994. Molecular interfacing for protein molecular devices and neurodevices. IEEE Eng Med Biol 13: 94-102.

Anaissi FJ, Demets GJF, Toma HE \& Coelho ACV 1999. Modified electrodes based on mixed bentonite vanadium(V) oxide xerogels. J Electroanal Chem 464: 48-53.

Angnes L, Azevedo CMN, Araki K \& Toma HE 1996. Electrochemical detection of NADH and dopamine in flow analysis based on tetraruthenated porphyrin modified electrodes. Anal Chim Acta 329: 91-95.

Anson FC, Shi C \& Steiger B 1997. Novel multinuclear catalysts for the electroreduction of dioxygen directly to water. Acc Chem Res 30: 437-444.

Araki K \& Toma HE 1991a. Synthesis and Electrochemical-Behavior of a Tetrametallated Cobalt Porphyrin. Inorg Chim Acta 179: 293-296.

Araki K \& Toma HE 1991b. Spectroelectrochemical Analysis of Overlapping Redox Processes in a Tetrametallated Iron Porphyrin. J Electroanal Chem 297: 301-307.

AraKi K \& Toma HE 1993. Synthesis and Characterization of a Multibridged Porphyrin Complex Containing Peripheral Bis(Bipyridine)-Ruthenium(Ii) Groups. J Coord Chem 30: 9-17.

ArAKI K \& Toma HE 1994a. Spectroelectrochemistry and Electrocatalytic Properties of a Tetraruthenated Nickel Porphyrin. J Chem Res-S p.290-290, 1994.

ARAKi K \& Toma HE 1994b. Luminescence, Spectroelectrochemistry and Photoelectrochemical Properties of a Tetraruthenated Zinc Porphyrin. J Photochem Photobiol A-Chemistry 83: 245-250.

Araki K, Angnes L \& Toma HE 1995a. Rectifying Properties and Photoconductivity of Tetraruthenated Nickel Porphyrin Films. Adv Mat 7: 554-559.

Araki K, Santos PS \& Toma HE 1993. Electronic and Resonance Raman-Spectra of a Multibridged Iron Porphyrin. Spectroscopy Lett 26: 1417-1426.

Araki K, Angnes L, Azevedo CMN \& Toma HE 1995b. Electrochemistry of a Tetraruthenated Cobalt Porphyrin and Its Use in Modified Electrodes As Sensors of Reducing Analytes. J Electroanal Chem 397: $205-210$.

Araki K, Santos PS, Deoliveria LFC \& Toma HE 1995c. Resonance Raman-Spectra of a Supramolecular Species Containing 4 Ruthenium(Ii) Bipyridine Complexes Attached to Zinc Tetrapyridyl Porphynate. Spectroscopy Lett 28: 118-126. 
Atwood JR, Davies JED \& MACNiCol DD 1996. Comprehensive Supramolecular Chemistry. v. 1-10, New York: Pergamon-Elsevier.

Azevedo CMN, Araki K, Angnes L \& Toma HE 1998. Electrostatically assembled films for improving the properties of tetraruthenated porphyrin modified electrodes. Electroanalysis 10: 467-471.

Azevedo CMN, Araki K, Toma He \& Angnes L 1999. Determination of sulfur dioxide in wines by gas-diffusion flow injection analysis utilizing modified electrodes with electrostatically assembled films of tetraruthenated porphyrin. Anal Chim Acta 387: 175-180.

Balzani V, Juris A, Venturi M, Campagna S \& Serroni S 1996. Luminescent and redox active polynuclear transition metal complexes. Chem Rev 96: 759.

Baumann JA, Salmon DJ, Wilson ST, Meyer TJ \& Hatfield W 1978. Electronic structure and redox properties of trinuclear ruthenium clusters. Inorg Chem 17: 3342-3350.

Bignozzi CA, Schoonover JR \& Scandola F 1997. A supramolecular approach to light harvesting and sensitization of wide-bandgap semiconductores: antenna effects and charge separation. Prog Inorg Chem 44: 1 .

BRUCE DW \& O’HARE D 1992. Inorganic Materials, New York: John Wiley.

Coombs RL \& Robinson DW 1996. Nanotechnology in Medicine and the Biosciences. In: (Ed.); 3, Amsterdam: Gordon and Breach.

CRANDALl BC 1997. Nanotechnology - Molecular speculations on global abundance. In: (Ed.); 1, Boston: MIT Press.

Dougherty TJ, Gomer CJ, Henderson BW, Jori G, Kessel D, Koorberlik M, Moan J \& Peng Q 1998. Photodynamic therapy. J. Natl Cancer Inst 90: 889-905.

DreXler KE 1986. Engines of Creation: Challenges and Choices of the Last Technological Revolution, Garden City, New York: Anchor Press.

Gust D, Moore TA \& Moore AL 1994. Photosynthesis mimics as molecular electronic devices. IEEE Eng Med Biol 13: 58-65.

Hartmann M \& Grabner EW 1991. Prussian blue-coated interdigitated array electrodes for possible analytical application. Anal Chim Acta 242: 249-257.

Hidalgo-LuangdiloK C \& Bocarsly AB 1990. Nickel-electrode confined [Ru(bipyrazine $)_{3}\left[\mathrm{Fe}(\mathrm{CN})_{5}\right]_{n}$ : an inorganic structural matrix yielding photoinduced multinuclear charge-transfer reactivity. Inorg Chem 29: 2894-2900.

ItAYA K, UChIDA I \& NeFF VD 1986. Electrochemistry of polynuclear transition metal cyanides: Prussian blue and its analogues. Acc Chem Res 19: 162-168.

KoHLE O, Ruile S \& GRÄTZEL M 1996. Ruthenium(II) charge transfer sensitizers containing 4,4,'dicarboxy2,2'bipyridine. Synthesis, properties and bonding mode of coordinated thio and selenocyanates. Inorg Chem 35: 4779-4787. 
Krishnamohan-Sharma CV, Broker GA, Duddleston JG, Baldwin JW, Metzger RM \& Rogers RD 1999. Design strategies for solid-state supramolecular arrays containing both mixed-metalated and free-base porphyrins. J. Am Chem Soc 121: 1137-1144.

LEHN J-M 1988. Supramolecular chemistry - scope and perspectives. Angew Chem Intl Ed 27: 89-112.

LEHN J-M 1995. Supramolecular Chemistry, Weinheim: VCH.

Livage J 1991. Vanadium pentoxide gels. Chem Mat 3: 578-593.

LiVAGE J 1996. Sol-gel chemistry and electrochemical properties of vanadium oxide gels. Solid state ionics 86: $935-942$.

Mallouk TE \& Gavin JA 1998. Molecular recognition in lamellar solids and thin films. Acc Chem Res 31: 209-217.

Nakano A, Osuka A, Yamazaki I, Yamazaki T \& Nishimura Y 1998. Windmill-like porphyrin arrays as potent light-harvesting antenna complexes. Angew Chem Intl Ed 37: 3023-3026.

Onuki J, Ribas AV, Medeiros MHG, Araki K, Toma HE, Catalani LH \& DiMascio P 1996. Supramolecular cationic tetraruthenated porphyrin induces single-strand breaks and 8-oxo-7,8-dihydro-2'-deoxyguanosine formation in DNA in the presence of light. Photochem Photobiol 63: 272-277.

Ravanat JL, Cadet J, Araki K, Toma HE, Medeiros MHG \& Di Mascio P 1998. Supramolecular cationic tetraruthenated porphyrin and light- induced decomposition of 2 '-deoxyguanosine predominantly via a singlet oxygen-mediated mechanism. Photochem Photobiol 68: 698-702.

Sauvage J-P, Collin J-P, Chambromn J-C, Guillerez S \& Coudret C 1994. Ruthenium(II) and osmiun(II) bis(terpyridine)complexes in covalently linked multicomponent systems: synthesis, electrochemical behavior, absorption spectra and photochemical and photophysical properties. Chem Rev 96: $759-767$.

Toma HE 1991. Desenvolvimento de supermoléculas - Em rumo à química supramolecular. Química Nova 14: $189-195$.

Toma HE \& ALEXIOU ADP 1995a. Synthesis and Characterization of a Dodecanuclear Ruthenium Pyrazine Cluster. J Braz, Chem Soc 6: 267-270.

Toma HE \& AlEXIOU ADP 1995b. Nuclear-Magnetic-Resonance and Spectroelectrochemical Characterization of a Supramolecular Tetrameric Ruthenium Cluster. J Chem Res-S 134-135.

TOMA HE \& ARAKI K 1988. Comportamento eletroquímico e espectroeletroquímico de uma porfirina polimetálica. Anais do VI Simpósio Brasileiro de Eletroquímica e Eletroanalítica: 183-190.

Toma HE \& Araki K 1990. Synthesis and Properties of a New Polymetallated Iron Porphyrin. J Chem Res-S 82-83.

Toma HE \& ChavezGiL TE 1997. Synthesis and characterization of a polymetallic supermolecule containing four ruthenium(II)-bipyridine complexes attached to an iron(II) polyimine center. Inorg Chim Acta 257: 197-202. 
Toma HE \& Cipriano C 1989a. Synthesis and Spectroscopic Characterization of Trinuclear [Ru3O(O2CCH3)6(Pyrazine)3]0,+ Clusters. Monatshefte Fur Chemie 120: 815-820.

Toma HE \& Cipriano C 1989b. Spectroelectrochemistry and Cyclic Voltammetry of the Trinuclear [Ru3O(O2CCH3)6(Pyrazine)3] Cluster. J Electroanal Chem 263: 313-322.

Toma HE \& CunHa CJ 1989. Spectroelectrochemical Behavior of the Trinuclear [Ru3O(O2CCH3)6(Isonicotinamide)3] Cluster. Canad J Chem-Rev Canad Chim 67: 1632-1635.

Toma HE \& Lever ABP 1986. Spectroscopic and Kinetic-Studies On a Series of Dinuclear to Heptanuclear Tris(Bipyrazine)Ruthenium(Ii)- Pentacyanoferrate(Ii) Complexes in Aqueous-Solution. Inorg Chem 25: 176-181.

Toma HE \& Olive MAL 1994. Spectroelectrochemical and Kinetic-Studies On the Interaction of Ruthenium-Edta With a Trinuclear Ruthenium Acetate Cluster Containing Aminopyrazine Ligands. Polyhedron 13: 2647-2652.

Toma HE \& Sernaglia RL 1993. Equilibria and Spectroelectrochemical Studies On the Formation of Multibridged Tris(Bipyrazine) Ruthenium(Ii) Complexes With Ruthenium-Edta Groups. Talanta 40: 515-520.

Toma HE, Araki K \& SiLva EO 1998. Synthesis and characterization of a novel dodecanuclear porphyrin ruthenium cluster. Monatshefte Fur Chemie 129: 975-984.

Toma HE, Cunha CJ \& Cipriano C 1988a. Redox Potentials of Trinuclear Mu-Oxo Ruthenium Acetate Clusters With N-Heterocyclic Ligands. Inorg Chim Acta 154: 63-66.

Toma HE, Matsumoto FM \& Cipriano C 1993. Spectroelectrochemistry of the Hexanuclear Cluster [Ru3O(Acetate)6-Mu-(Pyrazine)3-(Fe(CN)5)3]N- and of Its Modified Nickel Electrode in AqueousSolution. J Electroanal Chem 346: 261-270.

Toma HE, Oliveira HP \& Rechenberg HR 1994. Spectroscopic Characterization and Electrocatalytical Activity of Tetrapyridylporphyrins Intercalated Into Hydrated Vanadium (V) Oxide. J Incl Phenom Mol Recogn Chem 17: 351-363.

Toma HE, Santos PS \& Lever ABP 1988b. Resonance Raman-Spectra of the eptanuclear [Ru(Bpz)3(Ru(NH3)5)6]14+ Complex - Excitation Profiles For 3 Overlapping Metal-to-Ligand ChargeTransfer Bands. Inorg Chem 27: 3850-3853.

Toma He, Auburn PR, Dodsworth ES, Golovin MN \& Lever ABP 1987. Binding of Pentaammineruthenium(Ii) Residues to the Tris(Bipyrazine)Ruthenium(Ii) Cation. Inorg Chem 26: 4257-4263.

Toyama MM, Araki K \& Toma HE 1998a. Absorption and luminescence spectra of tetra(3-pyridyl)porphyrazine: A convergent spectroscopic method for the elucidation of association reactions in solution. Spectroscopy Lett 31: 1065-1074.

Toyama MM, Franco M, Catalani LH, Araki K \& Toma HE 1998b. Spectroelectrochemical and photophysical properties of a (3,4-pyridyl)porphyrazine supermolecule containing four $[\mathrm{Ru}(\mathrm{bipy})(2) \mathrm{Cl}](+)$ groups. J of Photochem Photobiol A-Chemistry 118: 11-17. 
SPENCER A \& WiLkinson G 1972. mu3-0xo-triuthenium carboxylate complexes. J Chem Soc Dalton Transactions: $1570-1577$.

WoNG FT 1994. Molecular electronics: science and technology for the future. IEEE Eng Med Biol 13: 25. 